\title{
日本農村医学会雑誌
}

\author{
第 65 巻 2016 年 7 月 第 2 号
}

\section{第64回学術総会シンポジウム I 「高齢者医療の現状と問題点」}

\section{資料：}

\section{当科における高齢者の肺炎の現状}

\author{
山本 真*
}

最近の高齢者肺炎の現状を理解するため下記の検討を試みた。対象は2010年 4 月から 5 年間の当科入院患者 3,784 名。

〔方法〕肺炎の診断と年齢で（65歳未満；若年群，65歳以上 ; 高齢群) 分類して解析した。 〔結果〕肺炎の入院患者は全体で718名（19\%），年齢中央值は78歳。若年群は118名年齢 中央值58歳であった。全入院患者に占める高齢群の割合は2011年には11\%であったが2014 年には $20 \% に$ 増加していた。死亡患者については高齢群が有意に多かった。（147名 vs15 名； p<0.05）在院日数の中央值では自宅退院, 死亡群とも両群に有意差を認めなかった が, 転院群では高齢群では中央值が48日であった。肺炎に関してはガイドラインが整備さ れており, 特に高齢者では特別な加療を要する場合は多くないため, 地域での病診・病病 連携を IT 化などでさらに強化し，一般病院・在宅での加療が可能にする必要がある。

\section{(1)肺炎 (2)高齢者 (3)転帰}

\section{は じめに}

2009年当時「どこで死を迎えるか みとりの 医療」という市民講演会で，急性期病院の立場 から以下の症例を提示した。症例は80歳後半の 女性。脳梗塞・心房細動で老健入所中。ADL は歩行不能で車いす座位は可能, 食事は全介 助。呼吸が促迫していたので, 近隣の病院を受 診。肺炎の診断。更に担当医から年齢，合併症

* = 080-0016 北海道帯広市西 6 条南8-1 带広厚生病院呼吸器内科 （受付：2016年 5 月10日）
を考慮すると寿命であり，命にかかわる可能性 が高いので同院に入院を勧められた。しかしな がら娘の希望で当院に搬送された。入院時の検 査所見では白血球の増加, CRP の高值があり, BUN 54.8mg/dl と脱水, $\mathrm{SpO} 299 \%$ と低酸素も 認めた。胸部レ線では左右特に左肺の透過性が 低下（図 1), CTR 増加あり, 当時は医療・介 護関連肺炎診療のガイドライン ${ }^{1)}$ がなかったの で，市中肺炎のガイドライン ${ }^{2)}$ を使用し A-DROP 3 点の重症肺炎と心不全と診断した。 早速抗生物質, 酸素療法を開始した。患者さん の娘は,「人工呼吸器は付けないんですか」と 問われたが, 入院後もどんどん低酸素が増悪し 


入院時検査成績
白血球 $\quad 18,000 / \mu \mathrm{l} \uparrow$
モモグロビン $10.4 \mathrm{~g} / \mathrm{dl}$
赤沈 $\quad 115 \mathrm{~mm} / \mathrm{h} \uparrow$
$\mathrm{C}$ 反応蛋白 $\quad 14.57 \mathrm{mg} / \mathrm{dl} \uparrow$
尿素窒素 $\quad 54.8 \mathrm{mg} / \mathrm{dl} \uparrow$
クレアチニン $1.18 \mathrm{mg} / \mathrm{dl} \uparrow$
経皮酸素飽和度 $89 \%($ 屋内気 $)$

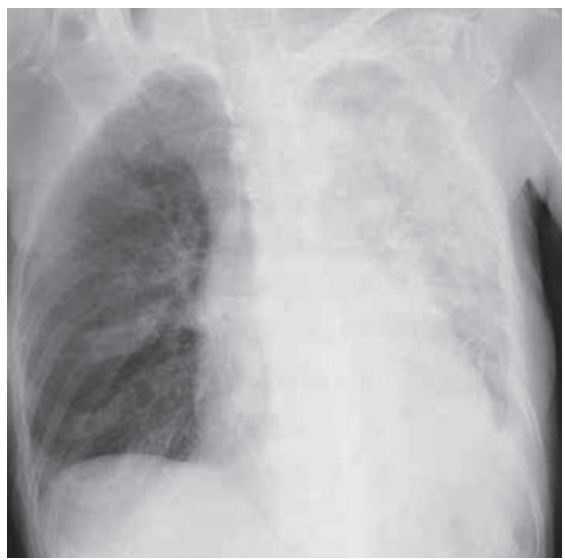

入院時胸部レントゲン写真

図 1。検査成績と胸部レントゲン写真

表 1.2008～2009当科入院患者の検討

\begin{tabular}{|c|c|c|c|}
\hline \multicolumn{4}{|c|}{$\begin{array}{c}2008.9 \text { ～2009.9 全入院患者747名の検討 } \\
\text { 市中肺炎入院患者 } 113 \text { 名（男性81名） } \\
\text { 死亡患者 治癒在院日数 }\end{array}$} \\
\hline 75歳以上 & 70名 & $20.8 \pm 17.3$ 日 & 中央值16日 \\
\hline 75歳以下 & $\begin{array}{l}\text { 6名 } \\
\text { NS }\end{array}$ & $\begin{array}{c}18.8 \pm 10.5 \text { 日 } \\
\mathrm{NS}\end{array}$ & 中央値16日 \\
\hline
\end{tabular}

ており，意識状態も混濁している状況を判断し た上で，「救命し得ることはほとんどない」と 説明し納得され，帰宅。その後 4 日間一度も病 院には来ず，死亡した 3 時間後に引き取りに来 た。という内容である。

このような症例を経験したので，高齢者肺炎 について 2008 年 9 月から 2009 年 9 月までの 1 年 間で当科の全入院患者が747名で肺炎に関して 分析してみた（表 1 )。肺炎の診断があったも のは113名 $(15 \%)$ であった。75歳以上70名と 75 歳以下は43名であり, 死亡患者が75歳以上 17 名 $(24 \%), 75$ 歳以下が 6 名 $(14 \%)$ であり， 有意差は認めなかった $\left(\chi^{2}\right.$ 乗検定 $)$ 。治癒退院 の在院日数は，中央值はいずれも16日間であっ た。つまり後期高齢者と75歳以下の肺炎は死亡 者数, あるいは在院日数では有意差がなかっ た。これはガイドラインに沿った治療をすれ ば，結果については年齢による差はないのでは ないかということであった。
厚生労働省で公表されている死因と死亡率3) では肺炎は2011年に既に 3 位（人口 10 万対 97.8）になっている（図 2 )。癌は人口10万対 90.3である。一方年齢別性別肺炎死亡率を, グ ラフ化すると，79歳を超えると男性では10万対 で338，とがんよりも多くなる（図 3 ）。

当院は, 北海道の東側で, 札幌との間に日高 山脈，北には大雪山系がある十勝地方にあり， 二次医療圈を形成している。十勝二次医療圈は 面積が 1 万平方キロあり（この秋田県とほぼ同 じ）で人口は 34 万 6,000 人である当院は基幹病 院・地方地域センター病院で748床を有してい る。他に 200 床以上は 4 病院あるが, 呼吸器内 科の専門医は当院のみにしかいない。

当院の高齢者肺炎の現状を知るために2010年 4 月から2014年 3 月までの 5 年間の当科入院患 者3,784名を対象に肺炎の診断で入院した方を 年歯令 65歳未満, 65歳以上に分類して解析した。 


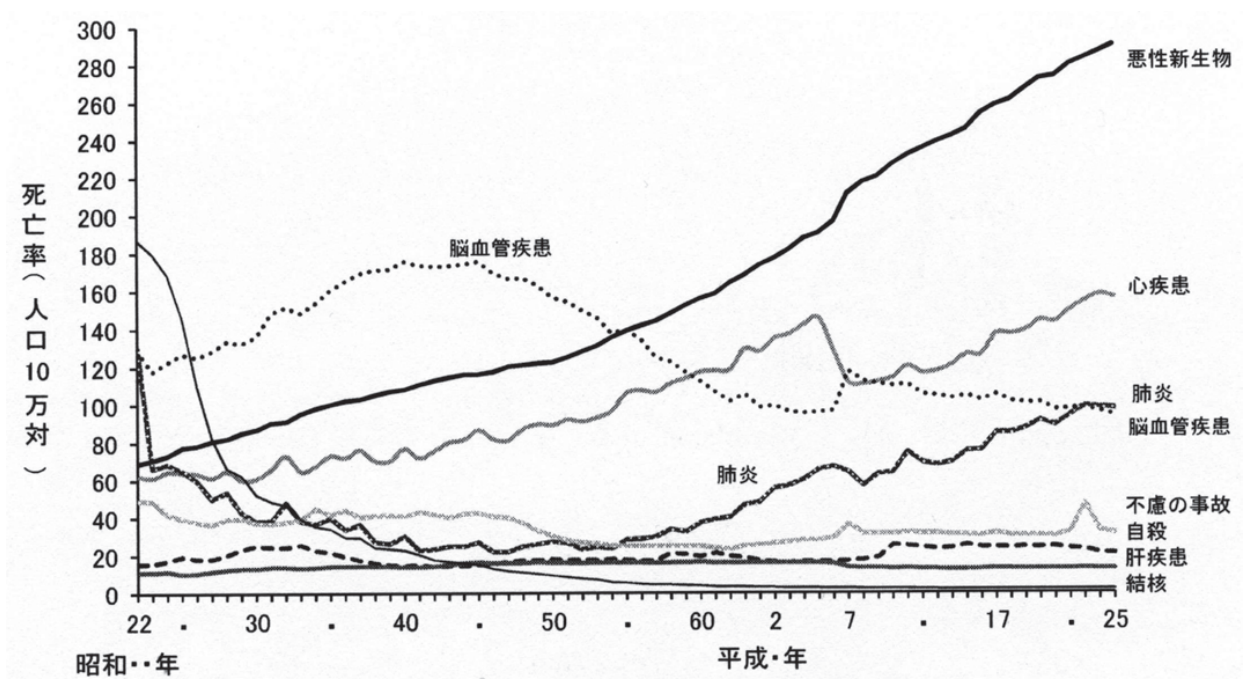

図 2. 主な死因別にみた死亡率の年次推移一昭和 22 年〜平成 25 年一

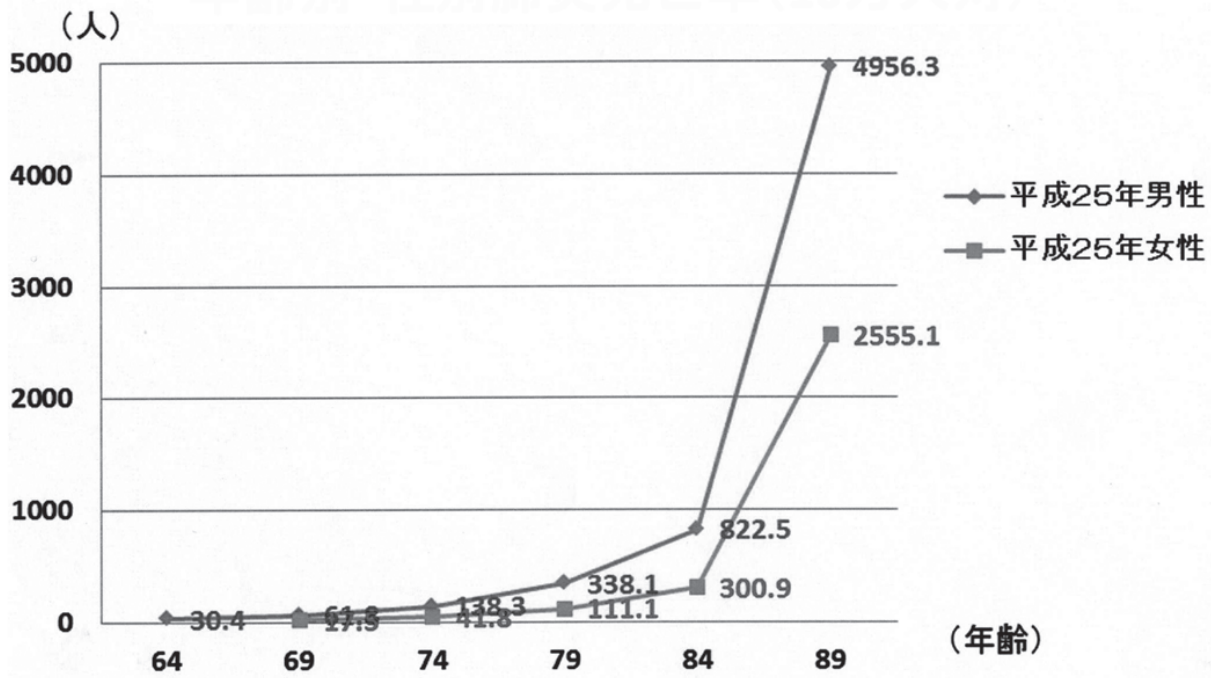

図 3 . 年齢別 - 性別肺炎死亡率（10万人対）(平成 25 年)

\section{結果}

肺炎の入院患者は 718 名（19\%）で年齢中央 值は78歳。65歳未満は118名で年齢中央值は58 歳。65歳以上は600名で年齢中央值は80歳で あった。65歳以上の肺炎の占める全入院患者の 割合では，2010年，2011年では11\%前後であっ たが。2014年では20\%近くに増加していた（図 4 )。肺炎の年齢分布で65歳以上が，80\%を占 め徐々に増加していた（図 5 ）。

日本呼吸器学会の肺炎診療ガイドラインは, 2005年に出された市中肺炎診療ガイドライン, 2008年に出された院内肺炎診療ガイドライ

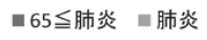

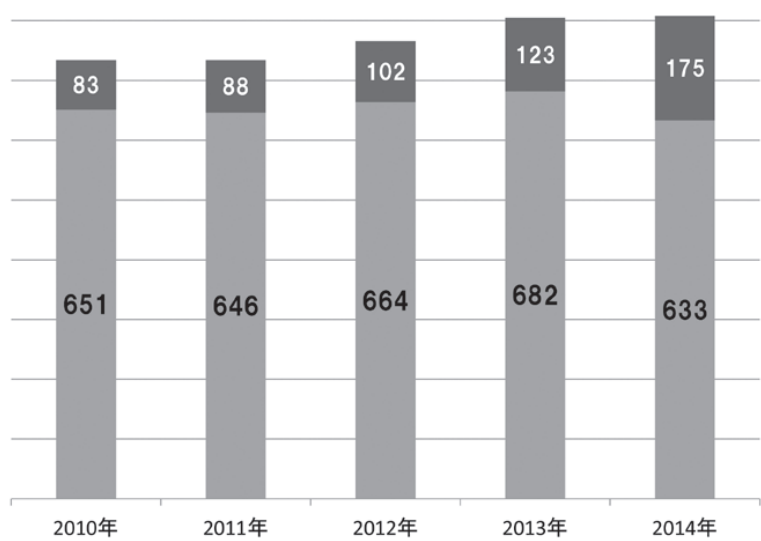

図 4.入院患者における65歳以上の占める割合 


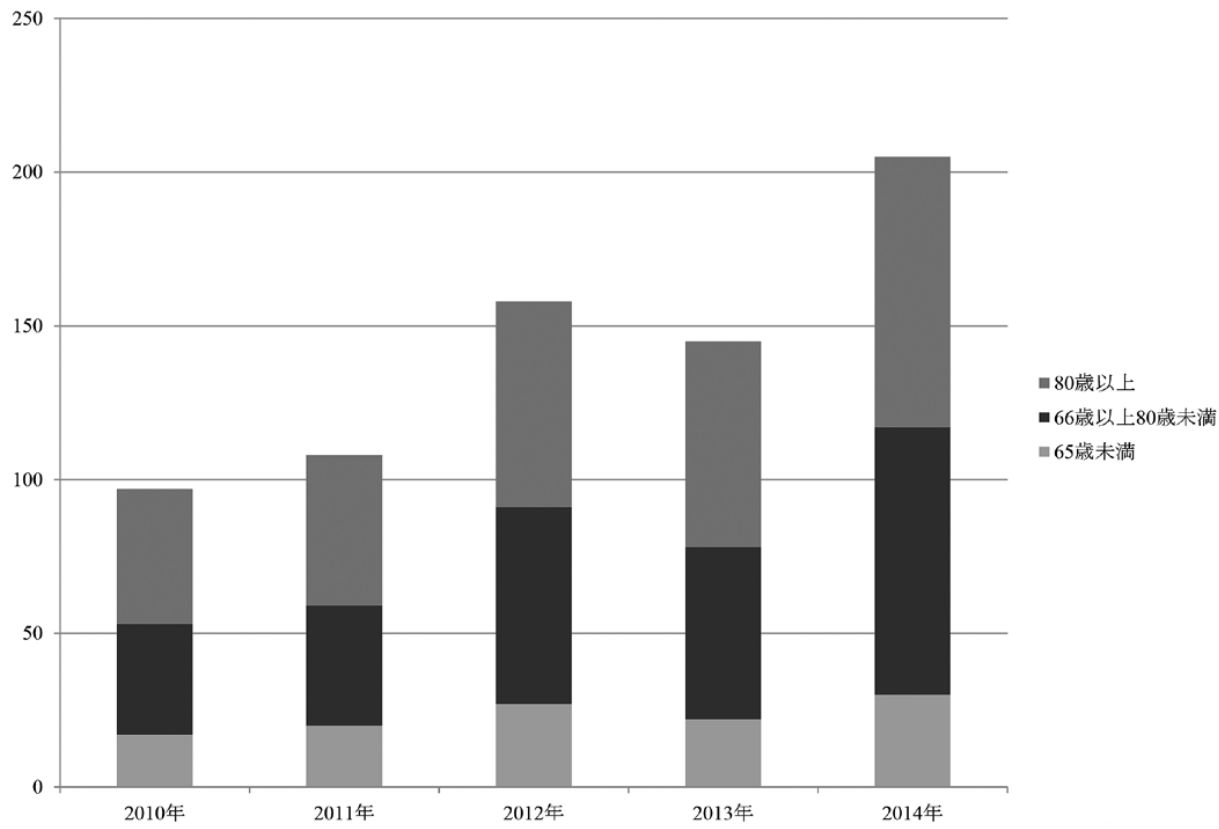

図 5 . 入院肺炎患者の年齢分布

表 2。重症度と予後

若年者

\begin{tabular}{lrrrrrr}
\hline ADROP & 0 & 1 & 2 & 3 & 4 & 5 \\
\hline$<65$ (死) & 0 & 5 & 3 & 3 & 3 & 0 \\
$<65$ (生) & 24 & 41 & 17 & 4 & 2 & 1 \\
\hline & & & & & \multicolumn{2}{c}{$\mathrm{p}<0.01$}
\end{tabular}

老齢者

\begin{tabular}{lrrrrrr}
\hline ADROP & 0 & 1 & 2 & 3 & 4 & 5 \\
\hline $65 \leqq$ (死) & 1 & 17 & 39 & 42 & 17 & 0 \\
$65 \leqq$ (生) & 16 & 86 & 137 & 92 & 16 & 0 \\
\hline
\end{tabular}

$\mathrm{p}<0.01$

ン ${ }^{4)}, 2012$ 年には医療・介護関連肺炎診療ガイ

ドラインが出ている。いずれも重症度の分類,

使うべき抗生物質が呈示されており，当院でも 基本的には準じて治療している。

肺炎718名を A-DROP (年齢, 脱水，低酸素 血症，意識障害，血圧）で分類して重症度を決 めた。やはり若年者65歳以下でも老齢者でも, 予後においては重症度が高いほど不良であっ た。同様な傾向であった（表 2 ）。

重症度と予後については, ADROP の $4 \cdot 5$

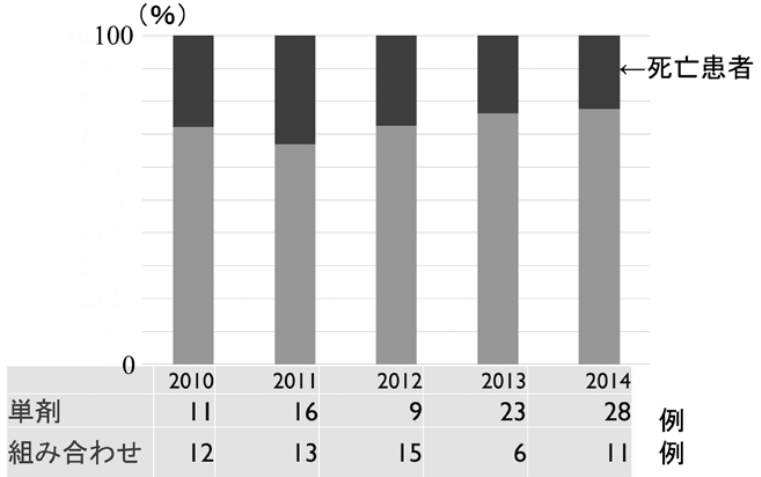

図 6. 抗菌薬使用の状況 30 日死亡率 $(65 \leqq)$ と抗菌剤

項目を満たした最重症では, 死亡患者が50\%を 超える。つまり当院患者から見てもガイドライ ンの妥当性が証明できた。

30日死亡率であるが徐々に減少してきてい る。死亡率低下の寄与因子として抗菌剤に注目 した。2013年頃から単剤で使う傾向があった (図 6 )。

死亡患者の呼吸に関する治療モードでは, 65 歳未満では15名の死亡患者であったが，気管内 挿管が 6 名, NPPVが 2 名。本人及び家族の 拒否で酸素投与のみが 7 名であった。一方65歳 以上では，147名の死亡患者で挿管が 5 名で あった（表 3 ）。 
表 3. 死亡患者の呼吸に関する治療の

モード(例)

\begin{tabular}{lccc}
\hline 年齢 $($ 死亡) & 気管内挿管 & NPPV & 酸素投与 \\
\hline$<65(15)$ & 6 & 2 & 7 \\
$65 \leqq(147)$ & 5 & 19 & 123 \\
\hline & & & $\mathrm{p}<0.01$
\end{tabular}

表 4 . 5 年間の検討

結果

\begin{tabular}{|c|c|c|c|c|}
\hline & 年齢 & 症例数 & 年齢中央値 & 在院日数中央値 \\
\hline \multirow[t]{2}{*}{ 自宅退院群 } & $<65$ & $80 / 118(68 \%)$ & $(18 \sim 64)$ & 12日（ $3 \sim 68 ）$ \\
\hline & $65 \leqq$ & $368 / 600(61 \%)$ & 74.5歳（65～99） & 15日（ $(2 \sim 192 ）$ \\
\hline \multirow[t]{2}{*}{ 転院群 } & $<65$ & $7 / 118(6 \%)$ & 59歳（53〜64） & 28日（19〜 70） \\
\hline & $65 \leqq$ & $60 / 600(10 \%)$ & $(68 \sim 100)$ & 48日（6～239） \\
\hline \multirow[t]{2}{*}{ 死亡退院群 } & $<65$ & $15 / 118(13 \%)$ & $(24 \sim 64)$ & 14日（1～77） \\
\hline & $65 \leqq$ & $147 / 600(25 \% *)$ & $(65 \sim 102)$ & 13日（ 1 ～127） \\
\hline
\end{tabular}

自宅退院群，転院群，死亡退院群に分類して 在院日数を検討した。自宅退院群では, 65歳以 下でも以上でも中央值はそれぞれ12日と15日で あった。死亡退院群でもそれぞれ14日と13日で あった。しかしながら転院群では跳ね上がる。 特に65歳以上で60名（10\%）いたが，中央值 48 日であった。尚 5 年間とも 40 日以上であった (表 4)。

結果をまとめると 1）当院の肺炎患者は増え る傾向にあった。その多くは65歳以上の高齢者 であった。2）肺炎患者の死亡率は若年者より 高齢者で有意に高く, 重症度が高いほど死亡率 が高い。3）リハビリや療養のための転院は, 高齢者ではその $10 \%$ に認められ, 在院日数が中 央值で他の患者の 3 倍以上であった。4）老齢 者でも自宅退院群・死亡退院群では在院日数は 若年者とほとんど変わらない。

当院においても他院呼吸器内科の引き上げの 影響を受けている可能性が示唆された。

\section{結論}

今後さらに人口の高齢化が起きるが, 呼吸器 内科医が減少しているので, 基幹病院での肺炎 の診療がさらに困難になる可能性がある。

ガイドラインが整備されており, さらなる普 及, そして地域での病診あるいは病病の相互連 携の IT 化などで, 長期加療のできる施設での 肺炎治療を，現場としては望みたい。

\section{著者の COI 開示}

本論文発表内容に関連して特に申告なし。

\section{文献}

1 ) 日本呼吸器学会編. 医療・ 介護関連肺炎 (NHCAP) 診療ガイドライン, 2012.

2 ) 日本呼吸器学会編. 市中肺炎診療ガイドライン, 2005.

3 ) 平成 25 年人口動態統計月報年計（概数）の概況 : 年次別に見た死因順位, 2013年; http://www. mhlw.go.jp/toukei/saikin/hw/jinkou/geppo/nengai13/dl/gaikyou25.pdf（2016.5.1アクセス）

4) 日本呼吸器学会編. 院内肺炎診療ガイドライン, 2008. 


\title{
Present Situation of Pneumonia in Elderly Inpatients of Our Respiratory Medicine Department
}

\begin{abstract}
Makoto YAMAMOTO*
To understand the present situation of elderly patients with pneumonia, all 3,784 inpatients of our Department of Respiratory Medicine from April 2010 to March 2015 were analyzed. In total, 718 patients (pts) were diagnosed with pneumonia (median age, 78 years) and they were classified into two groups: those aged $>65$ years (elderly group, EG: 600 pts and those $\leq 65$ years (younger group, YG; $118 \mathrm{pts}$ ). Annual change in the ratio of EG/YG, mortality rate, respiratory assist mode, and number of hospital days were analyzed. The ratio of EG/YG was 0.11 in 2011 but was higher at 0.20 in 2014 . The mortality rate was significantly higher in EG than in YG $(147 / 600$ vs $15 / 118 ; \mathrm{p}<0.05)$. In the group of deaths, among patients who were intubated, 6 of 15 were in YG and 5 of 147 were in EG, respectively. The median number of hospital days was not significantly different between the groups for patients who died (EG 13, YG 14) or were discharged (EG 15, YG 12). In EG, the proportion of patients who changed hospitals for recuperation was up to $10 \%$ and the median hospital stay was 48 days, compared to 28 days in YG. With regard to pneumonia, because the guidelines are well established and because elderly individuals, in particular, often do not require additional treatment, it is possible to provide treatment at general hospitals or at home by strengthening the cooperation between clinic and hospital as well as hospital and hospital in the community through the incorporation of information technology.
\end{abstract}

*Dept. of Respiratory Medicine, Obihiro Kosei General Hospital, Hokkaido, Japan 